\title{
In-Service Chemistry Teachers' Prior Knowledge Regarding STEM Integration in High School Chemistry Learning
}

\author{
Nur Fitriyana ${ }^{1, *}$, Antuni Wiyarsi ${ }^{1}$, Heru Pratomo $^{1}$, Marfuatun ${ }^{1}$, Annisa \\ Krisdiyanti $^{2}$, and Wahnutia Adilaregina ${ }^{2}$ \\ ${ }^{1}$ Chemistry Education Department, Faculty of Mathematics and Natural Sciences, Universitas Negeri \\ Yogyakarta, Indonesia \\ ${ }^{2}$ Student of Bachelor of Education in Chemistry Study Programme, Faculty of Mathematics and Natural \\ Sciences, Universitas Negeri Yogyakarta, Indonesia \\ *Corresponding author. Email: nur.fitriyana@uny.ac.id
}

\begin{abstract}
A good knowledge about Science, Technology, Engineering, and Mathematics (STEM) integration is essential for chemistry teachers before they are implementing a successful chemistry learning using STEM approach. This paper reported in-service chemistry teachers' prior knowledge in integrating STEM in high school chemistry learning. A descriptive study was adopted in this research. A number of 82 in-service chemistry teachers who teach in senior high schools in Yogyakarta were established as the research sample. Research sample was drawn from Sleman and Bantul Regency, Yogyakarta, Indonesia through saturated sampling. The initial knowledge about STEM of in-service chemistry teachers were captured using STEM Knowledge Questionnaire (STEM$\mathrm{KQ}$ ) consisting of 7 open-ended questions. The in-service chemistry teachers' response toward this STEM-KQ were analysed following qualitative descriptive method using content analysis with interpretative coding. The findings of this study revealed that in-service chemistry teachers have understand the basic concept of STEM, still it needs to be enhanced. Most of in-service chemistry teachers have known the definition and position of STEM. However, they still have a lack knowledge about the example of STEM implementation in the chemistry lesson. Therefore, the in-service chemistry teachers need to follow workshop that provide guidance on how to implement STEM approach in chemistry learning. Thus, through this activity, the in-service chemistry teachers develop their skills in preparing STEM learning that implied on their readiness in integrating STEM in the chemistry learning activities.
\end{abstract}

Keywords: In-service chemistry teachers, Prior knowledge, STEM approach, High school chemistry.

\section{INTRODUCTION}

The global economy and advancement of technology in the industrial revolution era of 4.0 requires human resources readiness that not only have excellent competencies but also be able to solve problems around them from various perspectives involving science and technology. Such conditions have been realized and anticipated by all parties including academics, researchers, and observers of education. This competency demand has changed students' views on how to learn, communicate, and interact with their surrounding environment in order to attain a better quality of live. Therefore, to meet this issue, the presence of STEM (Science,
Technology, Engineering, \& Mathematics) is essential as a part of educational reformation efforts and as a basis in providing future success [1,2]. The STEM integration also empowers students to be able to adapt and achieve a success in the rapidly changing of the world, including changes in chemistry education. Chemistry belongs to complex science that served as a foundation of another science. It can't be denied that chemistry content can't be understood by one perspective only. Accordingly, linking the chemistry concept with another science concept is needed in order to achieve comprehensive understanding, thus it will be meaningful to solve everyday problems. However, recent chemistry teaching only oriented on mastery 
the concept without relating with another point of view of different science field. Such when chemistry teachers taught chemical bonding topic, they explain the kind and structure of the bonding, but they did not deliver the application of those concept in the daily life that combine with another science field [3]. Still, many students in the field of chemistry have a lack experience in using the basic concepts of chemistry. This fact implied on the high number of students who encounter difficulties in processing information obtained when they are learning chemistry [4]. Therefore, facilitating students to link the chemistry concept with another science concept is needed in chemistry teaching in order to face real world problems.

STEM learning is very potential to train students in solving real world issues, thus the integration of STEM in chemistry learning activities strongly recommended [5]. Through STEM integration, students will be equipped and given experience about the use of STEM, such in applying the basic concepts of chemistry which applicable to the foundation in the lifelong learning process. Moreover, STEM approach is correlate the four fields of science covering the science, technology, engineering, and mathematics into one holistic union. Thus, STEM approach could encourage the student to designing, developing, and utilizing technology; sharpening their cognitive; and yielding science as the basis in learning chemistry. Since STEM learning allows the correlation of the four fields of science, it could develop students' higher order thinking skills and increase students' 21st century learning skills. STEM approach is essential as provisions and foundations for students to be success not only in the school but also in the subsequent levels [6], thus it should be widely implemented in chemistry teaching. However, the STEM integration is rarely conducted such in chemistry teaching, therefore the benefit of STEM in the chemistry teaching not felt yet.

On the other hand, the STEM approach is a new phenomenon that has received worldwide attention as a project to develop educational system [2]. STEM has been adopted by many programmes as an important focus to improve global competitiveness [7]. Through STEM, students could develop their interest in learning and increase their willingness to pursue in the STEM careers [8-12]. It also develops students' analytical thinking skills and attitudes towards science learning [13]; improves quantitative skills [14]; and enhances teachers' competencies [15]. Thus, the use of STEM is strongly considerable to be implemented in the teaching instruction. Unfortunately, the STEM integration in Indonesia still scarcely experienced. The main factor that makes this phenomenon happens caused by in-service teachers' knowledge or perception toward STEM learning in teaching chemistry [16]. The chemistry teachers should not only know the term and definition of STEM, but also familiar on how to integrate science which is chemistry combined with technology, engineering, and mathematics. They should understand about the basic concept of STEM, the urgency of the STEM approach, STEM integration in chemistry teaching, and the factors in implementing STEM in order to perceive meaningful chemistry teaching using STEM. Still, the STEM implementation was varied through several pedagogies, i.e., problem-based learning, discovery learning, project-based learning, and inquiry learning that signified on the optimization in improving chemistry teaching quality $[17,18]$.

Considering aforementioned discussion, as a subject that must be understood for high school students, delivering chemistry material needs to be designed in a meaningful way in order to increase students' motivation and interest in learning chemistry. The chemical content was delivered by the teacher must emphasize the relevance of chemical concepts to the lives of the students [19]. Through STEM, the relevance of chemistry materials to students' everyday lives will be clearer. Integrating STEM in this occasion is needed, as an effort to train students in solving everyday problems. Thus, as a basis in applying STEM, a good knowledge of inservice chemistry teachers about STEM in the chemistry teaching is essential before they could integrate STEM as a basis in delivering chemistry materials [20]. The more knowledge in-service teachers have, the more opportunity they will successfully implement STEM in chemistry teaching. This good knowledge regarding STEM integration will contribute the in-service teachers to be more confident in preparing, implementing, and evaluating STEM teaching [21]. Therefore, the purpose of this research accordingly to investigate in-service chemistry teachers' prior knowledge regarding STEM integration in high school chemistry learning. The research question guided the present study:

How was in-service teachers' prior knowledge regarding STEM integration in high school chemistry learning?

\section{METHODS}

The research methods covering the research design and participants, data collection, and data analysis conducted in this study explained in this section. 


\subsection{The Research Design and Participants}

This study adopted descriptive research, thus there was no experimental manipulation given toward the participants in this research. The participants in this research were in-service chemistry teachers who teach chemistry in senior high school in Sleman and Bantul regency, Yogyakarta, Indonesia. These samples established following saturated sampling technique since all of the in-service chemistry teachers in these two regencies were enrolled in the data collection process. However, there were several in-service chemistry teachers who did not response the instrument given by the researcher. Thus, only 82 in-service chemistry teachers who voluntary agree to participate in this research and response the instrument. A total number of this participants had similar economic background and had attained bachelor of education in chemistry degree as the requirement of chemistry teacher. However, they were varied in the term of gender, teaching experience, and teaching grade as shown in Table 1.

In order to achieve a meaningful learning using STEM integration in chemistry learning, a good understanding about STEM itself is essential. Thus, this research concerned on describing in-service chemistry teachers' initial knowledge toward STEM integration in chemistry learning. The sample collection was conducted one time, thus it indicated that the data of in-service chemistry teachers' prior knowledge about STEM were captured one time in a certain moment.

\subsection{Data Collection}

A non-test technique using STEM Knowledge Questionnaire (STEM-KQ) which consist of 7 openended questions was used to capture the data in this research. This STEM-KQ accordingly used to collect the data of in-service chemistry teachers' initial knowledge about STEM integration in chemistry teaching. The STEM-KQ covered 4 sub dimensions concerning STEM approach. They are basic knowledge about STEM approach; the possibility to implement STEM in chemistry teaching; the example of STEM integration in chemistry; also, the advantages and weakness using STEM in chemistry teaching, following [12,17,22-24]. The summary of open-ended questions with its indicator and subdimension on STEM-KQ was shown in Table 2.

Table 1. Demographic features of the participants

\begin{tabular}{|c|c|c|}
\hline Parameter & Frequency & Percentage (\%) \\
\hline \multicolumn{3}{|l|}{ Gender } \\
\hline Male & 16 & 19.51 \\
\hline Female & 66 & 80.49 \\
\hline \multicolumn{3}{|c|}{ Teaching Experience } \\
\hline$<1$ year & 6 & 7.32 \\
\hline $1-10$ years & 15 & 18.29 \\
\hline 11- 20 years & 29 & 35.37 \\
\hline$>20$ years & 32 & 39.02 \\
\hline \multicolumn{3}{|c|}{ Teaching Grade } \\
\hline$x$ & 13 & 15.85 \\
\hline$X I$ & 9 & 10.98 \\
\hline$X I I$ & 13 & 15.85 \\
\hline $\mathrm{X}$ and $\mathrm{XI}$ & 12 & 14.64 \\
\hline$X$ and $X I I$ & 7 & 8.54 \\
\hline $\mathrm{XI}$ and $\mathrm{XII}$ & 15 & 18.29 \\
\hline$X, X I$, and $X I I$ & 13 & 15.85 \\
\hline
\end{tabular}


Table 2. Open ended questions on STEM-KQ

\begin{tabular}{|c|c|c|c|}
\hline $\begin{array}{l}\text { Sub Dimension of } \\
\text { STEM }\end{array}$ & Indicators & $\begin{array}{l}\text { Question } \\
\text { Number }\end{array}$ & Question \\
\hline \multirow{2}{*}{$\begin{array}{l}\text { Basic knowledge } \\
\text { about STEM } \\
\text { approach }\end{array}$} & $\begin{array}{l}\text { Knowing the source of } \\
\text { STEM knowledge }\end{array}$ & 1 & $\begin{array}{l}\text { Have you heard the term of STEM? If you so, } \\
\text { where are you hear about it? }\end{array}$ \\
\hline & $\begin{array}{l}\text { Explaining the definition } \\
\text { of STEM approach }\end{array}$ & 2 & What do you know about STEM? \\
\hline \multirow{2}{*}{$\begin{array}{l}\text { Possibility to } \\
\text { implement STEM } \\
\text { in chemistry } \\
\text { teaching }\end{array}$} & $\begin{array}{l}\text { Giving point of view } \\
\text { about STEM integration in } \\
\text { chemistry teaching }\end{array}$ & 3 & $\begin{array}{l}\text { According to your opinion, does the STEM } \\
\text { approach could be used in chemistry } \\
\text { teaching? Give an example! }\end{array}$ \\
\hline & $\begin{array}{l}\text { Determining appropriate } \\
\text { chemistry materials to } \\
\text { integrate STEM approach }\end{array}$ & 4 & $\begin{array}{l}\text { What kind of chemistry materials that suitable } \\
\text { to implement STEM approach? Give an } \\
\text { example! }\end{array}$ \\
\hline $\begin{array}{l}\text { Example of STEM } \\
\text { integration }\end{array}$ & $\begin{array}{l}\text { Explaining in-service } \\
\text { teacher experience(s) in } \\
\text { implementing STEM } \\
\text { approach }\end{array}$ & 5 & $\begin{array}{l}\text { Have you implemented STEM approach in } \\
\text { chemistry teaching? Explain your answer! }\end{array}$ \\
\hline \multirow{2}{*}{$\begin{array}{l}\text { Advantages and } \\
\text { weakness using } \\
\text { STEM in chemistry } \\
\text { teaching }\end{array}$} & $\begin{array}{l}\text { Analysing the weakness } \\
\text { using STEM integration }\end{array}$ & 6 & $\begin{array}{l}\text { What is the weakness of STEM approach in } \\
\text { chemistry teaching? }\end{array}$ \\
\hline & $\begin{array}{l}\text { Analysing the advantages } \\
\text { using STEM approach }\end{array}$ & 7 & $\begin{array}{l}\text { What is the advantages of STEM approach in } \\
\text { chemistry teaching? }\end{array}$ \\
\hline
\end{tabular}

The content validation analysis was conducted before the STEM-KQ was used as the data collection tool in this research. Two experts were confirmed the content validity of the STEM-KQ. The experts were chosen due to their research record and experience in conducting STEM related research. They gave feedback about the STEM-KQ in the area of the appropriateness of STEM knowledge with the subdimension and the question, the appropriateness construction of the question, and the appropriateness of the Indonesian grammar rule. STEM-KQ was revised following the experts' feedbacks. Then, it was well distributed into the participants through online form. The participants need to response the STEM-KQ for 30 minutes

\subsection{Data Analysis}

The in-service chemistry teachers' response toward STEM-KQ were analysed following qualitative descriptive method. As suggested by Miles and Huberman [25], the analysis activity of qualitative data was done iteratively and continuously until complete. Moreover, the process of qualitative data analysis in this research employed content analysis with interpretative coding [26]. Hence, the in-service chemistry teacher response concerning their knowledge about STEM were analysed based on STEM concept. The coding process conducted on each question, thus each question had different number of themes. This qualitative analysis covering data reduction, data display, and verification.

\section{RESULTS AND DISCUSSION}

This section explains the findings of this research with its discussion. The findings of this research presented according to each open-ended question on STEM-KQ. Therefore, there were 7 coding results since this research used 7 open-ended question in this research, consisting the source of STEM knowledge, the definition of STEM approach, point of view toward STEM integration in chemistry teaching, appropriate chemistry materials to integrate STEM approach, in-service teacher experience(s) in implementing STEM approach, also advantages and weakness using STEM in chemistry teaching. 
Table 3. Reduction data on the source of STEM knowledge

\begin{tabular}{|l|l|l|}
\hline Response & Frequency & Percentage (\%) \\
\hline Short course regarding STEM & 10 & 12.50 \\
\hline Conference & 2 & 2.50 \\
\hline Internet, Journal, and Textbook & 10 & 12.50 \\
\hline Friend & 13 & 16.25 \\
\hline Workshop and technical guidance & 30 & 37.50 \\
\hline n/A & 8 & 10.00 \\
\hline
\end{tabular}

\subsection{The Source of STEM Knowledge}

The first question in the STEM-KQ was "Have you heard the term of STEM? If you so, where are you hear about it?". The participants' response for this question signified that $97.56 \%$ stated that they had heard about the term of STEM and the rest confirmed that they had not even heard the term of STEM. Thus, the term of STEM is familiar for most of in-service chemistry teachers in this research. The results of reduction data concerning the answer of this question presented in Table 3.

Examining the data on Table 3, most of in-service teacher have known the term of STEM through workshop and technical guidance (signified $37.50 \%$ from the total participants). Majority of these activities were held in chemistry subjects' teacher association or known as 'MGMP' in Yogyakarta, Indonesia. The organizing committee conducted this occasion in order to increase in-service chemistry teachers' competence using STEM approach. Thus, the Indonesian government are supporting the inservice chemistry teachers to apply STEM in their teaching activities. In addition, professional development programme designed to encourage the collaboration among in-service chemistry teachers in integrating STEM approach [27]. The in-service teachers could share their knowledge with others through MGMP in order to bring new insights in designing chemistry teaching [28]. The results of this research confirmed the previous work conducted by Nugroho, Permanasari, and Firman [29] that declare more than a half of the in-service teachers who participated in MGMP were help them to implement STEM teaching.

Phrased differently, despite through formal activities, in-service chemistry teachers knew the term of STEM informally by their friends; and another learning sources such as internet, journals, and textbook respectively $16.25 \%$ and $12.5 \%$. These values indicated that in-service chemistry teachers were curious about the term of STEM in chemistry teaching. Thus, they are looking for any resources about STEM to discern everything about STEM integration in chemistry teaching.

\subsection{The Definition of STEM Approach}

After most of the participants declared that they have been heard the term of STEM, the following question that asked was "What do you know about STEM?". Thus, the response regarding this question yields from the participants that stated have heard the STEM name. The reduction from the findings regarding this question were coded into 9 themes as seen in Table 4.

Table 4. The findings on the definition of STEM approach

\begin{tabular}{|l|l|l|}
\hline Response & Frequency & Percentage (\%) \\
\hline Modern teaching using recent technology & 2 & 2.50 \\
\hline Learning approach to overcome daily life problems & 9 & 11.25 \\
\hline Learning instruction that develop 21st century learning skills & 3 & 3.75 \\
\hline $\begin{array}{l}\text { Learning approach that integrates science, technology, engineering and } \\
\text { mathematics }\end{array}$ & 50 & 62.50 \\
\hline Multi-disciplinary learning & 6 & 7.50 \\
\hline Student centred learning & 4 & 5.00 \\
\hline
\end{tabular}




\begin{tabular}{|l|l|l|}
\hline Learning approach & 2 & 2.50 \\
\hline $\mathrm{n} / \mathrm{A}$ & 4 & 5.00 \\
\hline
\end{tabular}

The data on Table 4 shows that most of in-service chemistry teachers declared that STEM is an approach that integrates science, technology, engineering, and mathematics (signified as many as $62.50 \%$ of the total participants). Another response from in-service chemistry teachers implied that the STEM approach is a learning approach to overcome daily life problems, learning instruction to develop students' 21 st century learning skills, student centred learning instruction, and so on. As suggest by Kennedy and Odell [17], STEM is an approach that integrates technology and engineering into science and mathematics through scientific investigations and engineering process design. In line with Stohlman [24] that he describes STEM approach as an effort to integrate science, technology, engineering, and mathematics into one comprehensive knowledge. The STEM learning would be more effective if the inservice teachers had a good understanding concerning science discipline and figure out the chemistry concept from various science perspectives [30]. Thus, the in-service chemistry teachers' opinion regarding STEM definition is mostly correct.

On the other hand, only $5 \%$ of the participants' responses the definition of STEM can't be coded since they describe STEM approach into wrong definition. These participants explain STEM as learning method, learning system, and learning model. Still, this number of incorrect responses is small and is possible to be conceptually change by developing in-service chemistry teachers' knowledge regarding STEM through varied resources.

\subsection{Point of View of STEM Integration in Chemistry Teaching}

The following open-ended question regarding "According to your opinion, does the STEM approach could be used in chemistry teaching? Give an example!", aims to investigate in-service chemistry teachers' point of view in STEM integration in chemistry teaching. A total of $98 \%$ of the total participants suggest that STEM approach can be integrated in the chemistry teaching. Several participants giving their example about the activity that might become an option to implement chemistry teaching using STEM approach. The results of coding process concerning the example of STEM integration briefly presented in Table 5 .

Table 5 explains the example of STEM implementation in chemistry teaching according to in-service chemistry teachers' opinion. Making ice cream using the concept of freezing point depression and making a lamp using fruits as energy sources based on electrolyte and non-electrolyte solution concept became the most popular according to the participants when they need to integrate STEM in chemistry. In integrating STEM approach when teaching chemistry, the teacher should be linking the chemistry content with everyday phenomenon. Therefore, the relevance of chemistry teaching with daily life would reveal and it could increase students' interest and chemical literacy [19,31] also positive attitudes toward science $[32,33]$.

Table 5. The example of STEM integration in chemistry teaching

\begin{tabular}{|l|l|l|}
\hline Response & Frequency & Percentage (\%) \\
\hline $\begin{array}{l}\text { Making ice cream according to the concept of colligative properties of } \\
\text { solution }\end{array}$ & 4 & 18.18 \\
\hline Making 'rocket' using stoichiometry reaction & 1 & 4.54 \\
\hline Constructing measurement tool to investigate soil and water quality pH & 2 & 9.09 \\
\hline The tackling of polymer/ plastic waste & 2 & 9.09 \\
\hline Using RAR in electronic configuration materials & 1 & 4.54 \\
\hline Making environmentally friendly soap by tackling the waste of cooking oil & 2 & 9.09 \\
\hline Using QR code for compound nomenclature materials & 1 & 4.54 \\
\hline $\begin{array}{l}\text { Making a lamp using fruits as the energy sources following the electrolyte } \\
\text { and non-electrolyte solution also voltaic cell concept }\end{array}$ & 3 & 13.64 \\
\hline Designing prototype in polymer materials & 1 & 4.54 \\
\hline
\end{tabular}




\begin{tabular}{|l|l|l|}
\hline Making a jam based on colloid concept & 1 & 4.54 \\
\hline Water purifying using coagulation concept & 2 & 9.09 \\
\hline Phenomena of get electric shock & 1 & 4.54 \\
\hline Making a simple distillation apparatus & 1 & 4.54 \\
\hline
\end{tabular}

Table 6. Appropriate chemistry topics to integrate STEM approach

\begin{tabular}{|l|c|c|}
\hline Response & Frequency & Percentage (\%) \\
\hline Reduction-Oxidation Reaction and Electrochemistry & 27 & 25.00 \\
\hline Chemical Bonding & 2 & 1.85 \\
\hline Hydrocarbon & 9 & 8.33 \\
\hline Acid and Base & 11 & 10.18 \\
\hline Stoichiometry & 4 & 3.70 \\
\hline Colligative Properties Solution & 12 & 11.11 \\
\hline Polymerization & 3 & 2.78 \\
\hline Colloid & 6 & 5.56 \\
\hline Reaction Rate & 7 & 6.48 \\
\hline Chemical Nomenclature & 1 & 0.93 \\
\hline Thermochemistry & 5 & 4.63 \\
\hline Electrolyte-Non-Electrolyte Solution & 11 & 10.18 \\
\hline Chemical Equilibrium & 7 & 6.48 \\
\hline Petroleum & 2 & 1.85 \\
\hline n/A & 1 & 0.93 \\
\hline
\end{tabular}

\subsection{Appropriate Chemistry Topics to Integrate STEM Approach}

In this sub-dimension, the in-service chemistry teachers asked "What kind of chemistry topics that suitable to implement STEM approach? Give an example!". The participants' response concerning this question yields more than the total number of the participants since each participant could giving their point of view more than one. The findings concerning this question depict in Table 6. Table 6 describes the teaching topics that appropriate to implement STEM approach in chemistry teaching. It sought that majority of the in-service chemistry teachers state that STEM approach very suitable with redox reaction and electrochemistry concept. The in-service chemistry teachers' give the example of making voltaic cell using fruits solution extract or another material close to the students. Another example found that making mongoose peel extract as an antioxidant agent in the colligative properties of solution concept. Further, the in-service chemistry teachers explain that purifying water could become alternative in teaching colloidal material using STEM. Thus, as aforementioned discussion, the in-service chemistry teachers need to analyse the appropriate chemistry content along with the implementation of STEM approach.

The in-service chemistry teachers should make sure that the content topics could be integrated the four disciplines such as in the redox and electrochemistry concept which is electroplating [34]. According to science concept, the electroplating phenomenon describes the concept of electrolysis, electroplating, and Faraday law. Based on technology, presents the tools set, electrode, solution, and current sources. The engineering discipline covered the design of the metal coating procedures with certain layer thickness and area. Finally, according to Mathematics field, the electroplating phenomenon concern on calculating the mass of metal needed for metal coating with a certain layer thickness. Therefore, the in-service teachers should analyse the content of chemistry topics covering the four fields of STEM before they could integrate the STEM approach in chemistry teaching. 


\subsection{In-service Teacher Experience(s) in Implementing STEM Approach}

Another question that asks in-service chemistry teachers concern in their experience(s) in implementing STEM approach. The question "Have you implement STEM approach in chemistry teaching? Explain your answer!" yields that there are still limited number of in-service teachers have integrated STEM in their teaching activities. The number of in-service chemistry teachers that had implemented STEM teaching not exceed than a half of the total participants. It was implied that in-service chemistry teachers still have a lack of experience in integrating STEM. The participants who had integrated STEM describing their experience in the context of chemistry teaching.

Table 7. In-service teacher experience(s) in implementing STEM approach

\begin{tabular}{|c|c|}
\hline Participant & Experience(s) \\
\hline Participant 4 & $\begin{array}{l}\text { "I had used STEM approach for several chemistry topics such as asking the students to } \\
\text { make 'rocket' when teaching stoichiometry reaction topic, demanding the students to } \\
\text { create biodiesel when teaching petroleum topic, and making food product when } \\
\text { teaching acid-base topic". }\end{array}$ \\
\hline Participant 7 & $\begin{array}{l}\text { "I had been teaching introduction of chemistry in the everyday life for my students by } \\
\text { asking the students to make soap and hand sanitizer". }\end{array}$ \\
\hline Participant 10 & $\begin{array}{l}\text { "I've implemented STEM by asking the students to make healthy ice cream in the } \\
\text { colloid material". }\end{array}$ \\
\hline Participant 17 & $\begin{array}{l}\text { "Yes, making ice-cream using natural materials in the colligative properties solution } \\
\text { concept". }\end{array}$ \\
\hline Participant 33 & $\begin{array}{l}\text { "Yes, I have. In the molecular geometry material, I demand my students to create } \\
\text { sleeping lamp with the geometry of molecule. I've also used QR Code in teaching } \\
\text { nomenclature of the chemical compound material". }\end{array}$ \\
\hline Participant 49 & $\begin{array}{l}\text { "I had asked my student to design and create electrolyte and non-electrolyte solution } \\
\text { tool and tested it in the sea water of Parangtritis Beach". }\end{array}$ \\
\hline Participant 50 & $\begin{array}{l}\text { "Yes, I have implemented STEM approach by demanding the students to make natural } \\
\text { indicator in the acid base material". }\end{array}$ \\
\hline Participant 76 & "Yes, the students need to design the distillation tool and the procedure to purify water". \\
\hline Participant 48 & $\begin{array}{l}\text { "Yes, by asking the students to create distillation tool and gilding tool also making ice } \\
\text { cream". }\end{array}$ \\
\hline Participant 81 & "I have demanded my students to design a processing plastic waste into fuel". \\
\hline
\end{tabular}

Several participants' responses toward their experience in integrating STEM presented in Table 7. Examining the data on Table 7, the participants describe very good example regarding their experience in integrating STEM. The participants explain the implementation of STEM to overcome everyday issues just like making antioxidant ice cream from mongoose peel using colligative properties solution, colloid, and even stoichiometric concept. The implementation of STEM approach in the chemistry teaching is considerably such an interesting learning environment. However, the number of participants still have a lack experience and skill in integrating STEM. Thus, they need to improve their skills to prepare chemistry teaching through any resources.

\subsection{The Weakness Using STEM Integration}

The following question asks the participants' opinion regarding the drawbacks of STEM integration in high school chemistry teaching. They asked "What is the weakness of STEM approach in chemistry teaching?". The participants' response 
concerning this question classified into 7 groups as shown in Table 8. The fewer number of the participants that have not yet been implemented STEM approach related to the weakness of STEM approach in chemistry lesson. Seeing the data presented in the Table 8 , most of in-service chemistry teachers revealed that they need longer time allocation in implementing STEM teaching. This difficulty in line with Sheffield et al. [35] work that suggest the drawbacks of STEM approach caused by the limited time allocation, teacher competence, and the curriculum. Pedagogy competences were needed to improve teachers' ability in managing the STEM teaching. the teachers need to be creative, accept other ideas, and had rational thinking when teaching STEM [36]. Another difficulty encounter by the participants is not all of chemistry materials could be teach using STEM approach. They state that it is difficult to design chemistry teaching in the certain chemistry topic. The in-service chemistry teachers analyse the chemistry concept that appropriate to be implemented using STEM should have several characteristics i.e., the content that emphasize with the context, practice, solution, problem and product making.

\subsection{The Advantages Using STEM Approach}

Not only the drawbacks, the participants also describe the advantages using STEM approach in chemistry teaching. Accordingly, the last question aims to examine in-service chemistry teachers' point of view regarding the advantages of STEM teaching by asking "What is the advantages of STEM approach in chemistry teaching?". Table 9 presents the findings concerning this question, it yields 8 groups theme.

Table 8. The drawbacks of STEM integration

\begin{tabular}{|c|c|c|}
\hline Response & Frequency & Percentage (\%) \\
\hline Limited in the certain materials and competence & 14 & 17.07 \\
\hline Need longer time allocation in perceiving teaching instruction & 33 & 40.24 \\
\hline Require complete facilities and infrastructures & 7 & 8.54 \\
\hline Influenced by the ability of students & 8 & 9.76 \\
\hline Requiring a good teachers' competencies & 10 & 12.20 \\
\hline Limited on tools, materials, and costs & 3 & 3.66 \\
\hline Do not know & 5 & 6.09 \\
\hline $\mathrm{n} / \mathrm{A}$ & 2 & 2.44 \\
\hline
\end{tabular}

Table 9. The advantages in integrating STEM

\begin{tabular}{|l|c|c|}
\hline Response & Frequency & Percentage (\%) \\
\hline $\begin{array}{l}\text { Increasing 4C competencies (Critical Thinking, Communication, } \\
\text { Creativity, Collaboration) }\end{array}$ & 21 & 25.61 \\
\hline $\begin{array}{l}\text { Enhancing students' understanding and application of the learning } \\
\text { materials in everyday lives }\end{array}$ & 33 & 40.24 \\
\hline Improving students' interest and motivation to learn chemistry & 14 & 17.07 \\
\hline $\begin{array}{l}\text { Upgrading in-service teachers' creativity in designing learning } \\
\text { environments }\end{array}$ & 2 & 2.44 \\
\hline $\begin{array}{l}\text { Increasing students' engagement since STEM belongs to student centred } \\
\text { learning paradigm }\end{array}$ & 6 & 7.32 \\
\hline Following the development of 21st century learning & 1 & 1.22 \\
\hline Yielding a product & 1 & 1.22 \\
\hline Utilizing materials that close with students' life & 1 & 1.22 \\
\hline n/A & 3 & 3.66 \\
\hline
\end{tabular}


The findings about participants' opinion on STEM integration describe in Table 9 were revealed that most of in-service chemistry teachers agree that STEM could enhances students' understanding and application of the learning materials in daily lives. It also increases students' 21 st century learning skills competencies covering critical thinking, communication, creativity, and collaboration confirmed by $[37,38]$ work. Further, as suggest by Roberts et al. [39] the STEM approach brings the students to gain a new experience that elaborate their understanding on STEM content and attract their interest. Only $3.66 \%$ from the total of participant state that they are not know the advantages of STEM integration. This number implied on the participants' awareness toward the benefits using STEM in chemistry teaching to attain meaningful chemistry learning.

\section{CONCLUSION}

Designing chemistry learning environment that could attract students' engagement and motivation in learning chemistry become the challenge for all of chemistry teachers. The presence of STEM teaching is likely possible to increase students' interest in learning chemistry. It also develops students' 21 st century learning competencies such as critical thinking, communication, creativity, and collaboration. Therefore, the implementation of STEM approach should be considerable to be implemented in chemistry teaching. However, the chemistry teachers should have a good knowledge about STEM before they are applying STEM approach in chemistry teaching in order to maintain meaningful learning for the students. The findings of this research revealed that in-service chemistry teachers' prior knowledge regarding STEM were equally good. Almost all of the teachers have understood the definition and position of STEM. Unfortunately, they had a lack experience concerning the example of STEM implementation in chemistry lesson. Therefore, they require to accompany workshop that supply a guidance on the step of implementing STEM in chemistry lesson. This activity brings the in-service chemistry teachers develop their understanding, knowledge, and experience in preparing STEM teaching in chemistry. Thus, a meaningful chemistry learning using STEM approach could be achieved.

Considering the findings of this research, it suggests to examine the effectiveness of the implementation of STEM integration in chemistry teaching with a deep analysis. The survey could be conducted in the term on how the in-service chemistry teachers integrate STEM using varied pedagogies such as project-based learning [17,36]; problem-based learning [17]; inquiry learning [18] and blended learning [40]. The blended learning became a considerable choice since it could develop students' self-efficacy [41] and students' selfregulated learning $[42,43]$. Therefore, the STEM integration in chemistry teaching not only increase students' cognitive but also students' affective and behaviour. Seeing the result of this research, the collaborative learning based STSE could be performed with the distinction of chemistry subject areas and the grade level with the extent of research samples. For future studies, it is suggested to use blended learning mode in delivering chemistry content knowledge using STSE approach because the presence of online learning in this mode gives significant effects on students' self-efficacy as the part of motivation expectancy value [44] and students' self-regulated learning [43]. Moreover, the addition of computer assisted instruction could be employ because it enables in improving students' performance and motivation in the certain subject [18] such as through flipped class room [40]. Thus, the effectiveness of collaborative learning based STSE in comprehensive result will be reveal.

\section{AUTHORS' CONTRIBUTIONS}

This study was a part of research group of the first until fourth author. The research activities taken by the fifth and sixth author as their undergraduate thesis project under the supervision of the first four authors.

\section{ACKNOWLEDGMENTS}

The authors would like to thank Universitas Negeri Yogyakarta for funding this research through Research Group Grant of 2020.

\section{REFERENCES}

[1] E. Bullock, Only STEM can save us? Examining race, place, and STEM education as property, Educational Studies 53(6) (2017) 628-641. DOI: https://doi.org/10.1080/00131946.2017.1369082

[2] M. Tan, Why STEM? Why now? Educating for technologies, or technologies for education?, Learning: Research and Practice 4(2) (2018) 203-209.

DOI: https://doi.org/10.1080/23735082.2018.1511275

[3] W. I. Subagia, Paradigma baru pembelajaran kimia SMA, Prosiding Seminar Nasional FMIPA UNDIKSHA IV 4 (2014) 152-163. 
[4] J. M. Scaramozzino, Integrating STEM information competencies into an undergraduate curriculum, Journal of Library Administration 50(4) (2010) 315-333. DOI: https://doi.org/10.1080/01930821003666981

[5] S. Aydin-Gunbatar, A. Tarkin-Celikkiran, E. S. Kutucu, \& B. Ekiz-Kiran, The influence of a design-based STEM education, Chem. Educ. Res. Pract. 19(3) (2018) 954-972. DOI: https://doi.org/10.1039/c8rp00128f

[6] J. L. Wendt, A. Rockinson-Szapkiw, \& M. Cordes, Examining the influence of a STEM certification model on female, minority science outcomes, The Journal of Educational Research, 111(6) (2018) 666-677. DOI: https://doi.org/10.1080/00220671.2017.1396437

[7] J. M. Breiner, S. S. Harkness, C. C. Johnson, \& C. M. Koehler, What is STEM? A discussion about conceptions of stem in education and partnerships, School Science and Mathematics 112(1) (2012) 3-11. DOI: https://doi.org/10.1111/j.19498594.2011.00109.x

[8] K. Miller, G. Sonnert, \& P. Sadler, The influence of students' participation in STEM competitions on their interest in STEM careers, International Journal of Science Education, Part B 8(2) (2018) 95-114. DOI: https://doi.org/10.1080/21548455.2017.1397298

[9] T. A. Franz-Odendaal, K. Blotnicky, F. French, \& P. Joy, Experiences and perceptions of STEM subjects, careers, and engagement in STEM activities among middle school students in the Maritime Provinces, Canadian Journal of Science, Mathematics and Technology Education 16(2) (2016) 153-168. DOI: https://doi.org/10.1080/14926156.2016.1166291

[10] M. G. Jones, G. Childers, E. Corin, K. Chesnutt, $\&$ T. Andre, Free choice science learning and STEM career choice, International Journal of Science Education Part B (2018) 1-11. DOI: https://doi.org/10.1080/21548455.2018.1534024

[11] S. Chachashvili-Bolotin, M. Milner-Bolotin, \& S. Lissitsa, Examination of factors predicting secondary students' interest in tertiary STEM education, International Journal of Science Education 38(3) (2016) 366-390. DOI: https://doi.org/10.1080/09500693.2016.1143137

[12] E. H. M. Shahali \& L. Halim, Bitara-STEM training of trainers' programme: impact on trainers' knowledge, beliefs, attitudes and efficacy towards integrated stem teaching
Journal of Baltic Science Education 14(1) (2015) 85-95.

[13] P. Chonkaew, B. Sukhummek, \& C. Faikhamta. Development of analytical thinking ability and attitudes towards science learning of grade-11 students through science technology engineering and mathematics (STEM education) in the study of stoichiometry, Chem. Educ. Res. Pract. 17(4) (2016) 842-861. DOI: https://doi.org/10.1039/c6rp00074f

[14] J. Reid, \& J. Wilkes, Developing and applying quantitative skills maps for STEM curricula, with a focus on different modes of learning, International Journal of Mathematical Education in Science and Technology, 47 (2016) 837-852.

DOI: https://doi.org/10.1080/0020739X.2016.114481 4.

[15] W. Du, D. Liu, C. C. Johnson, T. A. Sondergeld, V. L. J. Bolshakova, \& T. J. Moore, The impact of integrated STEM professional development on teacher quality, School Science and Mathematics 119(2) (2019) 105-114. DOI: https://doi.org/10.1111/ssm.12318

[16] F. F. Mardiyah, Persepsi guru kimia ma setangerang selatan tentang pendekatan STEM, Universitas Islam Negeri Syarif Hidayatullah, 2019.

[17] M. R. Kennedy, Engaging students in STEM education, Science Education International 25(3) (2014) 246-258.

[18] S. Psycharis, The impact of computational experiment and formative assessment in inquirybased learning approach in STEM education, Journal of Science Education \& Technology 25 (2016) 316-326.

[19] J. Holbrook, \& M. Rannikmae, The nature of science education for enhancing scientific literacy, International Journal of Science Education 29(11) (2007) 1347-1362.

[20] K. C. Margot, \& T. Kettler, Teachers' perception of STEM integration and education: A systematic literature reciew, Int J STEM Educ 6(2) (2019) 1-16. DOI: https://doi.org/10.1186/s40594-018-0151-2

[21] E. B. Altan, \& S. Ercan, STEM Education Program for Science Teachers: Perceptions and Competencies, Journal of Turkish Science Education, 13 (2016) 103-117. DOI: https://doi.org/10.12973/tused.10174a

[22] El-Deghaidy, Science teachers' perceptions of STEM education: Possibilities and challenges, 
International Journal of Learning and Teaching 1(1) (2015) 51-54. DOI: https://doi.org/10.181178/ijlt.1.1.51-54

[23] L. Ariani, Sudarmin, \& S. Nurhayat, Analisis berpikir kreatif pada penerapan problem-based learning berpendekatan Science, Technology, Engineeering and Mathematics, Jurnal Inovasi Pendidikan Kimia 13(1) (2019) 2307-2317. DOI:

https://journal.unnes.ac.id/nju/index.php/JIPK/ar $\underline{\text { ticle/view/15159 }}$

[24] M. T. Stohlmann, Considerations for teaching integrated STEM Education, Journal of PreCollege Engineering Education Research (JPEER) 2(1) (2012) 28-34. DOI: https://doi.org/10.5703/1288284314653

[25] A. Hubberman, \& M. Miles, Analisis data kualitatif edisi terjemahan, Universitas Indonesia, 2005.

[26] J. W. Creswell Research design: Qualitative, quantitative, and mixed methods approaches, SAGE Publications, Inc, 2014.

[27] B. Kelcey, \& G. Phelps, Considerations for designing group randomized trials of professional development with teacher knowledge outcomes, Educational Evaluation and Policy Analysis 35(3) (2013) 370390. DOI:

https://doi.org/10.3102/0162373713482766

[28] M. Rismark, \& A. M. Sølvberg, Knowledge sharing in schools: A key to developing professional learning communities, World Journal of Education 1(2) (2011) 150-160. DOI: http://dx.doi.org/10.5430/wje.v1n2p150.

[29] O. F. Nugroho, A. Permanasari, \& H. Firman, (2019). The movement of STEM education in Indonesia: Science teachers' perspectives, Jurnal Pendidikan IPA Indonesia 8(3) (2011) 417425.

DOI:

https://doi.org/10.15294/jpii.v8i3.19252

[30] J. Ejiwale, Facilitating teaching and learning across STEM fields, Journal of STEM Education 13(3) (2012) 177. DOI: https://doi.org/10.11591/edulearn.v6i3.161

[31] A. Wiyarsi, H. Pratomo, \& E. Priyambodo, Vocational high school students' chemical literacy on context-based learning: a case of petroleum topic Journal of Turkish Science Education 17(1) (2020) 147-161. DOI: http://dx.doi.org/10.36681/tused.2020.18.

[32] S. Cepni, B. B. Ulger \& U. Ormanci, Pre-service science teachers' views towards the process of associating science concepts with everyday life, Journal of Turkish Science Education 14(4) (2017) 1-15. DOI: https://doi.org/10.12973/tused.10208a

[33] M. Calık, \& W. W. Cobern, A cross-cultural study of CKCM efficacy in an undergraduate chemistry classroom, Chem. Educ. Res. Pract. 18(4) (2017) 691-709. DOI: https://doi.org/10.1039/c7rp00016b

[34] P. K. Devi, S. Karyana, \& L. Nulhakim, Elektrokimia: electroplating/pelapisan logam, South East Asia Ministry of Education Organization (SEAMEO QIETP) In Science, 2018.

[35] S. Sheffield, R. Koul, S. Blackley, E. Fitriani, Y. Rahmawati, \& D. Resek, Transnational examination of STEM education, International Journal of Innovation in Science and Mathematics Education 26(8) (2018) 67-80.

[36] A. Asghar, R. Ellington, E. Rice, F. Johnson, \& G. M. Prime, Supporting STEM education in secondary science contexts Interdisciplinary Journal of Problem-Based Learning 6(2) (2012) 85-125. DOI: https://doi.org/10.7771/1541$\underline{5015.1349}$

[37] H. A. Basha, Investigating teachers' perceptions and implementation of STEM education in the United Arab Emirate [Dissertation] (2018) UAE, The British University in Dubai.

[38] R. B. Toma, \&I. M. Greca, The effect of integrative STEM instruction on elementary students' attitudes toward science, EURASIA J Math Sci Tech Ed 14(4) (2018) 1383-95. DOI: https://doi.org/10.29333/ejmste/83676

[39] T. Roberts, C. Jackson, M. J. Mohr-Schroeder, S. B. Bush, C. Maiorca, M. Cavalcanti, D. C. Schroeder, A. Delaney, L. Putnam, \& C. Cremeans, Students' perceptions of STEM learning after participating in a summer informal learning experience, International Journal of STEM Education 5 (2018) 35. DOI: https://doi.org/10.1186/s40594-018-0133-4.

[40] B. Wibawa, \& S. Kardipah, The flipped-blended model for STEM education to improve students' performances, International Journal of Engineering \& Technology 7(2) (2018) 2-29. DOI:

http://dx.doi.org/10.14419/ijet.v7i2.29.14298

[41] N. Fitriyana, A. Wiyarsi, \& K. H. Sugiyarto, The profile of students' self-efficacy on hydrocarbon hybrid learning and android-basedgame, International Journal of New Trends in 
Education and Their Implications 9(2) (2018) 115.

[42] N. Fitriyana, A. Wiyarsi, J. Ikhsan, \& K. H. Sugiyarto, Fostering of students' self-regulated learning and achievement: A study on hydrocarbon hybrid-learning and chemondrogame, J. Phys.: Conf. Ser. 1097 (2018) 012064. DOI: $\quad$ http://dx.doi.org/10.1088/1742$\underline{6596 / 1097 / 1 / 012064}$

[43] A. Wiyarsi, N. Fitriyana, \& J. Ikhsan, Using technology in hydrocarbon topics: A profile on students' self-regulated learning, Journal for the Education of Gifted Young Scientists 7(4) (2019) 961-972. DOI: http://dx.doi.org/10.17478/jegys.2018.82

[44] N. Fitriyana, A. Wiyarsi, J. Ikhsan, \& K. H. Sugiyarto, Andoroid-based-game and belended learning in chemistry: Effect on students' selfefficacy and achievement, Cakrawala Pendidikan 39(3) (2020) 507-521. DOI: https://doi.org/10.21831/cp.v39i3.28335 